\title{
Effect of sealing on the feed out face of trench silos on the performance of confined calves
}

\author{
[Efeito da vedação na porção inicial de silos trincheiras sobre o desempenho de novilhos confinados] \\ M. Neumann ${ }^{1}$, F.B. Cristo ${ }^{2}$, G.B. Pontarolo ${ }^{2}$, A.M. Souza ${ }^{3}$, M.P. Machado ${ }^{4}$, \\ R.S. Oliveira ${ }^{4}$, T.F. Gavlak ${ }^{4}$, A.D. Manchur ${ }^{4}$ \\ ${ }^{1}$ Universidade Estadual do Centro Oeste/Unicentro - Guarapuava, PR \\ ${ }^{2}$ Aluno de pós-graduação - Universidade Estadual do Centro Oeste/Unicentro - Guarapuava, PR \\ ${ }^{3}$ Aluno de pós-graduação - Universidade Estadual de Londrina/UEL - Londrina, PR \\ ${ }^{4}$ Aluno de graduação - Universidade Estadual do Centro Oeste/Unicentro - Guarapuava, PR
}

\begin{abstract}
This study aimed to evaluate the productive performance, dry matter intake, apparent digestibility and ingestive behavior of feedlot calves fed corn silage from the feed out face of trench silos with different types of sealing. The animals were divided into three treatments with four repetitions: Conventional seal double-sided polyethylene of $110 \mu \mathrm{m}$ thickness; Double-sided seal - double-sided polyethylene of $200 \mu \mathrm{m}$ thickness; and Double seal - composed of double face polyethylene with a thickness of $80 \mu \mathrm{m}$ superimposed on a polyamide translucent vacuum film with a thickness of $20 \mu \mathrm{m}$. The use of double face sealing provided $12.63 \%$ increase in average daily gain and improved food conversion by 0.62 percentage points. The apparent digestibility of the diet with double-face sealing system silage was $4.30 \%$ higher than the diet with double-face sealing silage and $11.00 \%$ higher than the diet with conventional sealing silage. It is recommended to use the double face sealing with $200 \mu \mathrm{m}$ polyethylene and double face sealing with $80 \mu \mathrm{m}$ thick polyethylene on top of a $20 \mu \mathrm{m}$ thick polyamide translucent vacuum film.
\end{abstract}

Keywords: ingestive behavior, plastic film, feed efficiency, weight gain, polyethylene

\section{RESUMO}

Objetivou-se avaliar o desempenho produtivo, o consumo de matéria seca, a digestibilidade aparente e o comportamento ingestivo de novilhos confinados, alimentados com silagem de milho da porção inicial de silos do tipo trincheira, conservada sob distintos tipos de vedação. Os animais foram divididos em três tratamentos, com quatro repetições: vedação convencional - polietileno tipo dupla face, com espessura

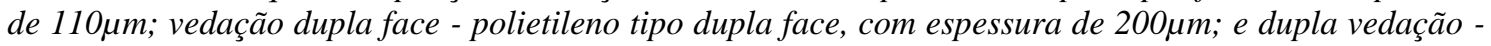

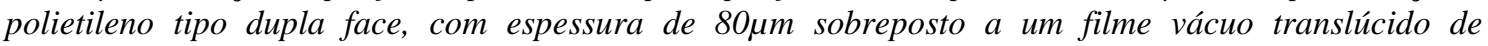
poliamida, com espessura de $20 \mu \mathrm{m}$. O uso da vedação dupla face proporcionou incremento de $12,63 \%$ no ganho de peso médio diário e melhorou em 0,62 ponto percentual a conversão alimentar. A digestibilidade aparente da dieta com silagem do sistema de vedação dupla face foi 4,30\% superior em relação à dieta com silagem da dupla vedação e 11,00\% superior à dieta com silagem da vedação convencional. Recomenda-se a utilização tanto da vedação dupla face com polietileno de $200 \mu$ um quanto

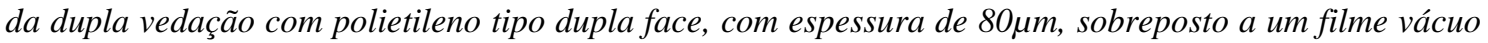
translúcido de poliamida com espessura de $20 \mu \mathrm{m}$.

Palavras-chave: comportamento ingestivo, filme plástico, eficiência alimentar, ganho de peso, polietileno

\section{INTRODUCTION}

The type of sealing used in corn silage production has a great importance for an adequate fermentation, which is carried out by lactic acid bacteria that convert soluble sugars into organic acids, such as lactic acid, under

Recebido em 24 de novembro de 2020

Aceito em 24 de fevereiro de 2021

*Autor para correspondência (corresponding author)

E-mail: fernandobragacristo@gmail.com anaerobiosis, which influences the preservation of the nutritional quality of ensiled material. Therefore, the adequate sealing of a corn silage can minimize the loss of nutrients and that the chemical composition and digestibility of the original material are preserved (Borreani et al., 2007; Neumann et al., 2017). For a proper fermentation, it is essential to achieve anaerobic 
conditions (Wilkinson and Davies, 2013). However, for several reasons, such as poor material quality, low thickness, high permeability of the plastic film and perforations caused when closing the silo or during the storage period, make it difficult to achieve anaerobiosis inside the silo (Borreani et al., 2007; Bernardes et al., 2012).

In general, sealing must be uniform throughout the silo, but there is greater difficulty in compacting and correctly sealing the lateral and feed out faces (ramp) of the trench silo, making them more prone to deterioration, due to greater exposure to the external environment and temperature fluctuations, making the environment conducive to the action of aerobic microorganisms that promote spoilage of ensiled forage (Kung Junior, 2005; Bernardes, 2016). Many nutritionists decide to discard these portions of the silo for considering them of poor quality, low animal response and high health risk to animals regarding the real situation of the rest of the silo.According to Neumann et al. (2018), the type of material used to seal the silo can positively affect the preservation of silage, resulting in higher productive performance of the animals, stimulating the daily dry matter intake and allowing less participation of the concentrated fraction in the diets. Plastic films based on double-sided polyethylene (white on black) are still the most used material to cover trench silos in Brazil (Bernardes et al., 2015), films with thickness ranging from 80 to $120 \mu \mathrm{m}$ are the most common.

However, the demand for cover that maintain an anaerobic environment and with less temperature fluctuation inside the silo has stimulated the development of plastic films with less permeability to oxygen and UV rays and greater mechanical resistance, which allows the efficient preservation of the ensiled mass and reduces nutrient losses during fermentation (Borreani et al., 2007). Based on this purpose, the present study aimed to evaluate the productive performance, dry matter intake, apparent digestibility and ingestive behavior of feedlot steers fed corn silage from the feed out face of trench silos preserved using different types of sealing.

\section{MATERIAL AND METHODS}

The experiment was conducted at the Animal Production Center (NUPRAN) of the Agricultural and Environmental Sciences Sector, State University of the midwest (UNICENTRO), municipality of Guarapuava, State of Paraná. All experimental procedures were previously submitted to the Committee for Ethics in Animal Experimentation (CEUA) of UNICENTRO and approved for execution (Official Letter 021/2018). Corn (Zeamays, L.) was planted on $02 / 11 / 2017$, using seeds of the early cyclehybridmaximus Viptera 3 (Syngenta ${ }^{\circledR}$ ), with the purpose of producing grains and silage, with hard textured grains and resistance to Glyphosate.

Under no-till farming, seeds were sown in rows spaced $0.80 \mathrm{~m}$ apart, $0.04 \mathrm{~m}$ sowing depth and distribution of 5 seeds per linear meter, for a final population of 62.5 thousand plantsha ${ }^{-1}$. Corn plants were harvested at 145 days after emergence at a kernel dough stage, with the aid of a precision forage harvester $\mathrm{JF}^{\circledR}$ model $(\mathrm{C}-120$ AT S2), to an average particle size of $10 \mathrm{~mm}$. The material collected for each treatment was stored in 12 trench silos, with $15 \mathrm{~m}$ in length, $1.2 \mathrm{~m}$ in width and $1.2 \mathrm{~m}$ in eighth. The opening of the same occurred simultaneously, 75 days after ensiling, and the handling for silo unloading occurred for 35 days removing only the initial face of the silo (ramp), with a daily removal of $0.15 \mathrm{~m}$.

Twenty-four calves, $1 / 2$ Angus Nellore blood, whole males, from the same herd, with an average initial weight of $300 \mathrm{~kg}$ and an average age of 10 months, were previously adapted to the diets and feedlot management on the farm of origin. The animals were housed in 12 feedlot pens, semi-roofed, with an area of $15 \mathrm{~m}^{2}$, with a concrete feeder and a water trough regulated by an automatic float. They were previously dewormed and selected from a herd based on body weight and condition and then distributed in a completely randomized experimental design, consisting of three treatments: $\mathrm{T}_{1}$ Conventional seal- corn silage preserved with double-sided polyethylene of $110 \mu \mathrm{m}$ thickness; $\mathrm{T}_{2}$ Doublesided seal- corn silage preserved with doublesided polyethylene of $220 \mu \mathrm{m}$ thickness; and T3 Double seal- corn silage preserved with oxygenimpermeable film composed of double-sided 
polyethylene of $80 \mu \mathrm{m}$ thickness on a translucent vacuum polyamide film of $20 \mu \mathrm{m}$ thickness, with four repetitions each, where each repetition consisted of a silo and/or a pen with two animals.

The conventional seal consisted of using doublesided (Plus Agrolord ${ }^{\circledR}$ ) polyethylene plastic film, $110 \mu \mathrm{m}$ thick, from the company Basso Pancote, Brazil. The double-sided seal consisted of using a double-sided plastic film (polyethylene with a thickness of $200 \mu \mathrm{m}$, from the company Carga Pesada, Brazil). In the double seal treatment, we used the plastic film (Polydress ${ }^{\circledR} \mathrm{O}_{2}$ Barrier 2IN1, which has a layer of $80 \mu \mathrm{m}$ of a protective film of polyethylene, overlaid on a layer of translucent vacuum polyamide film with $20 \mu \mathrm{m}$ thickness, which ensures impermeability to oxygen, from RKW, Germany). The experiment lasted for 35 days, 5 days for adaptation of animals to diets and facilities and two periods of evaluation with 15 days each.

Food management was carried out twice a day (6h and 1.6h) and consumption was recorded daily, by means of the difference in weight between the amount supplied and leftovers from the previous day. The supply adjustment was carried out daily, aiming at an "ad libitum" offer, considering 5\% leftovers, on a dry matter basis of the diet. During the feedlot period, samples of corn silage and concentrate were taken for analysis of the chemical composition of the diet (Table 1). Samples were dried in a ventilated oven at $55{ }^{\circ} \mathrm{C}$ to constant weight, and sequentially ground in a Wiley mill with a $1 \mathrm{~mm}$ sieve.

The contents of dry matter (DM), crude protein $(\mathrm{CP})$, mineral matter (MM) and ether extract (EE) were determined according to AOAC (Official..., 1995). The content of neutral detergent fiber (NDF) was obtained according to the method of Van Soest et al. (1991) with thermostable $\alpha$-amylase and acid detergent fiber (ADF) and lignin (LIG) contents were determined according to Goering e Van Soest (1970). The coefficient of total digestible nutrients (TDN) was calculated according to Weiss et al. (1992).

The diets consisted of the three corn silages, from different types of sealing, at a constant ratio of $40 \%$ forage (corn silage from different types of sealing) and $60 \%$ concentrate, on a dry matter basis (Table 1). The concentrate was prepared in the commercial feed factory of Cooperative Agrária (Guarapuava, Paraná, Brazil), formulated based on soybean meal $(4.00 \%)$, corn $(13.70 \%)$, wheatmeal $(25.00 \%)$, soybean husk $(4.00 \%)$, malt root $(21.00 \%)$, barley $(15.00 \%)$, corn germ $(10.40 \%)$ calcitic limestone $(3.60 \%)$, dicalcium phosphate $(0.50 \%)$, livestock urea $(1.50 \%)$, common salt $(0.60 \%)$, and mineral vitamin premix $(0.70 \%)$, in pellets. The chemical composition of the concentrate showed average values of $90.40 \%$ dry matter, $6.36 \%$ mineral matter, $20.20 \%$ crude protein, $2.05 \%$ ether extract, $31.47 \%$ neutral detergent fiber, $13.08 \%$ acid detergent fiber, $4.73 \%$ lignin, $78.68 \%$ total digestible nutrients, $1.67 \% \mathrm{Ca}$ and $0.58 \% \mathrm{P}$, based on total dry matter and with guarantee levels of premix per $\mathrm{kg}$ concentrate of vit. A of $16,000 \mathrm{IU}$, vit D3 of 2,000 IU, vit. E $25 \mathrm{IU}, \mathrm{S}$ $0.36 \mathrm{~g}, \mathrm{mg} 0.74 \mathrm{~g}, \mathrm{Na} 3.6 \mathrm{~g}$, Co $0.52 \mathrm{mg}, \mathrm{Cu}$ $22.01 \mathrm{mg}$, I $1.07 \mathrm{mg}$, mn $72.80 \mathrm{mg}$, Se $0.64 \mathrm{mg}$ and $\mathrm{Zn} 95.20 \mathrm{mg}$.

Feedlot steers fed corn silages from the feed out face of trench silos with different types of sealing were evaluated for dry matter intake, animal performance, apparent digestibility, ingestive behavior and in situ ruminal disappearance rate. Animals were weighed at the beginning, in the middle and at the end of the experiment, after solid fasting for 10hours, to determine the average daily weight gain (ADG). The daily dry matter intake, expressed in $\mathrm{kg}$ day $^{-1}$ (DMI, $\mathrm{kg}$ day $^{-1}$ ) or expressed as a percentage of body weight (DMI, BW\%) was measured through the difference between the daily amount of food supplied and the number of leftovers from the previous day. To determine feed conversion (FC), the ratio of the average daily dry matter intake to the average daily weight gain obtained in the evaluation period $\left(\mathrm{DMI}_{\mathrm{Kgday}-1} \mathrm{ADG}^{-1}\right)$ was calculated.

In the middle of the feedlot period, the total feces from each experimental unit were collected for 48 consecutive hours. Feces were weighed and sampled at the end of each six-hour shift. Subsequently, they were dried in a ventilation oven at $55^{\circ} \mathrm{C}$ to constant weight and ground in a Wiley mill with a $1 \mathrm{~mm}$ sieve. This procedure allowed the determination of the fecal dry matter content, and sequentially estimation of the total fecal output on a dry matter basis, expressed in $\mathrm{kg}$ day $^{-1}$ dry matter. To estimate the apparent 
digestibility of dry matter (DMS), homogeneous samples of the diet and feces were taken for analysis. The DMS, expressed in $\mathrm{g} \mathrm{kg}^{-1} \mathrm{DM}$, was calculated using the formula: Digestibility $\{1-$ $[$ (nutrient ingested - nutrient excreted $) \div$ nutrient ingested] \} x 100 .

Table 1. Chemical composition of silages and experimental diets

\begin{tabular}{|c|c|c|c|}
\hline \multicolumn{4}{|c|}{ Type of sealing- Corn silage } \\
\hline Chemical composition & Conventional Seal & Double Sided & Double Seal \\
\hline Dry matter, $\%$ & 41.22 & 42.58 & 42.83 \\
\hline Mineral matter, \% DM & 2.91 & 3.36 & 2.71 \\
\hline Crude protein, \% DM & 6.01 & 6.72 & 6.06 \\
\hline Neutral detergent fiber, \% DM & 54.86 & 51.33 & 53.36 \\
\hline Acid detergent fiber, \% DM & 29.23 & 27.06 & 28.98 \\
\hline Lignin, \% DM & 6.96 & 6.66 & 6.56 \\
\hline Total digestible nutrients, $\%$ & 67.38 & 68.90 & 67.55 \\
\hline & \multicolumn{3}{|c|}{ Type of sealing - Experimental diets } \\
\hline Chemical composition & Conventional Seal & Double Sided & Double Seal \\
\hline Dry matter, $\%$ & 70.73 & 71.27 & 71.37 \\
\hline Mineral matter, \% DM & 4.98 & 5.16 & 4.90 \\
\hline Crude protein, \% DM & 14.52 & 14.81 & 14.54 \\
\hline Neutral detergent fiber, \% DM & 40.83 & 39.41 & 40.23 \\
\hline Acid detergent fiber, \% DM & 19.54 & 18.67 & 19.44 \\
\hline Lignin, \% DM & 5.62 & 5.50 & 5.46 \\
\hline Total digestible nutrients, $\%$ & 74.16 & 74.77 & 74.23 \\
\hline
\end{tabular}

Observations of the ingestive behavior were made for $48 \mathrm{~h}$, by four observers per shift, in a rotation system every $6 \mathrm{~h}$. The readings were taken at regular intervals of $3 \mathrm{~min}$. the ingestive behavior was represented by idle, rumination, water intake and food intake activities, expressed in hours day ${ }^{-1}$. In addition, we observed the frequency of the occurrence of feeding, watering, urination and defecation activities, expressed in number of times per day, following the same methodology. In the night observation, the environment was maintained with artificial lighting. During the 30 experimental days, feces of each pen were evaluated daily by means of visual observation scores.

Feces were classified by scores, ranging from 1 to 6 , in which: $1=$ liquid feces, mushy; $2=$ liquid feces, mushy, with small piles of up to $2.5 \mathrm{~cm} ; 3$ $=$ intermediate feces with concentric ring and 3 to $4 \mathrm{~cm}$ pile; $4=$ pasty feces with concentric ring and pile of more than $5 \mathrm{~cm} ; 5=$ drier stools without concentric ring and pile greater than $5 \mathrm{~cm} ; 6=$ hardened or dried stools, based on the methodology adapted from Looper et al. (2001) and Ferreira et al. (2013).

Besides the ranking of feces scores, a visual assessment of dietary leftovers was also performed daily in relation to the proportion of corn silage and concentrate, on a dry matter basis. The leftovers were ranked using visual scores, from 1 to 5 , with $1=60 \%$ silage and $40 \%$ concentrated; $2=50 \%$ silage and $50 \%$ concentrate $3=40 \%$ silage and $60 \%$ concentrate; $4=30 \%$ silage and $70 \%$ concentrate; $5=20 \%$ silage and $80 \%$ concentrate; and $6=10 \%$ silage and $90 \%$ concentrate, on a dry basis. The ruminal disappearance rate of dry matter and neutral detergent fiber of silages was estimated using the in-situ technique according to the methodology by Nocek (1988). The incubation times for determining the ruminal disappearance rate of dry matter and neutral detergent fiber were 0,6 , $12,24,36$ and $48 \mathrm{~h}$, in reverse order of incubation time.

Data on performance, apparent digestibility and ingestive behavior were tested by ANOVA, with subsequent comparison of means by Tukey's test at $5 \%$ significance, using the GLM procedure of SAS (1993). The following statistical model was used: $\mathrm{Yi}=\mu+\mathrm{Ti}+\mathrm{Ei}$, where: $\mathrm{Yi}=$ response criterion; $\mu=$ overall mean common to all observations (constant); $\mathrm{Ti}=$ effect of the $\mathrm{i}$-th treatment; and $\mathrm{Ei}=$ random error inherent in all observations. The data collected regarding the ruminal disappearance rate of $\mathrm{DM}$ and $\mathrm{NDF}$ 
were also subjected to polynomial regression analysis, using the "proc reg" procedure (SAS, 1993).

\section{RESULTS AND DISCUSSION}

The treatment of double-sided sealing provided corn silage with better quality, and feedlot steers fed this silage showed an increase of $12.63 \%$ (P $<0.05)$ in the ADG in relation to the animals that received the silage from the conventional sealing $\left(1.892 \mathrm{~kg}\right.$ day $^{-1}$ against $1.653 \mathrm{~kg}$ day $^{-1}$, respectively), the steers that were given silage from the double seal had intermediate ADG and not different $(\mathrm{P}>0.05)$ from the other types of sealing (Table 2).

Table 2. Average daily gain, daily dry matter intake, feed conversion and ingestive behavior regarding aspects of feeder and feces scores of feedlot steers fed corn silage from the feed out face of trench silos with different types of sealing associated with feedlot period

\begin{tabular}{|c|c|c|c|}
\hline \multirow[b]{2}{*}{ Types of sealing } & \multicolumn{2}{|c|}{ Silage emptying phase } & \multirow[b]{2}{*}{ Mean } \\
\hline & $\begin{array}{l}\text { 1st Period } \\
1-15 \text { days }\end{array}$ & $\begin{array}{l}2^{\text {nd }} \text { Period } \\
16-30 \text { days }\end{array}$ & \\
\hline & \multicolumn{3}{|c|}{ Average daily gain, $\mathrm{kg} \mathrm{day}^{-1}$} \\
\hline Conventional Seal & 1.428 & 1.878 & $1.653 \mathrm{~B}$ \\
\hline Double Sided & 1.756 & 2.028 & $1.892 \mathrm{~A}$ \\
\hline Double Seal & 1.439 & 2.044 & $1.742 \mathrm{AB}$ \\
\hline \multirow[t]{2}{*}{ Mean } & $1.541 \mathrm{~b}$ & $1.983 \mathrm{a}$ & \\
\hline & \multicolumn{3}{|c|}{ Dry matter intake, $\mathrm{kg} \mathrm{day}^{-1}$} \\
\hline Conventional Seal & 7.39 & 8.29 & $7.84 \mathrm{~A}$ \\
\hline Double Sided & 7.62 & 8.24 & $7.93 \mathrm{~A}$ \\
\hline Double Seal & 7.38 & 8.36 & $7.87 \mathrm{~A}$ \\
\hline \multirow[t]{2}{*}{ Mean } & $7.46 \mathrm{~b}$ & $8.30 \mathrm{a}$ & \\
\hline & \multicolumn{3}{|c|}{ Dry matter intake , $\%$ body weight } \\
\hline Conventional Seal & 2.29 & 2.36 & $2.32 \mathrm{~A}$ \\
\hline Double Sided & 2.35 & 2.32 & $2.33 \mathrm{~A}$ \\
\hline Double Seal & 2.27 & 2.35 & $2.31 \mathrm{~A}$ \\
\hline \multirow[t]{2}{*}{ Mean } & $2.30 \mathrm{a}$ & $2.34 \mathrm{a}$ & \\
\hline & \multicolumn{3}{|c|}{ Feed conversion $\left(\mathrm{DMI} \mathrm{ADG}^{-1}\right)$} \\
\hline Conventional Seal & 5.57 & 4.47 & $5.02 \mathrm{~A}$ \\
\hline Double Sided & 4.69 & 4.11 & $4.40 \mathrm{~B}$ \\
\hline Double Seal & 5.30 & 4.12 & $4.71 \mathrm{AB}$ \\
\hline \multirow[t]{2}{*}{ Mean } & $5.19 \mathrm{a}$ & $4.23 \mathrm{~b}$ & \\
\hline & \multicolumn{3}{|c|}{ Daily feedlot score } \\
\hline Conventional Seal & 2.16 & 2.53 & $2.35 \mathrm{~A}$ \\
\hline Double Sided & 2.20 & 2.20 & $2.20 \mathrm{~A}$ \\
\hline Double Seal & 1.86 & 2.17 & $2.02 \mathrm{~A}$ \\
\hline \multirow[t]{2}{*}{ Mean } & $2.07 \mathrm{a}$ & $2.31 \mathrm{a}$ & \\
\hline & \multicolumn{3}{|c|}{ Daily feces score } \\
\hline Conventional Seal & 2.98 & 2.86 & $2.91 \mathrm{~A}$ \\
\hline Double Sided & 3.06 & 3.04 & $3.07 \mathrm{~A}$ \\
\hline Double Seal & 3.11 & 3.02 & $3.06 \mathrm{~A}$ \\
\hline Mean & $3.06 \mathrm{a}$ & $2.98 \mathrm{a}$ & \\
\hline \multicolumn{4}{|c|}{$\begin{array}{l}\text { Averages, followed by lowercase letters on the line, differ by F Test at } 5 \% \text {. } \\
\text { Averages, followed by upper case letters in the column, differ from each other by the 5\% Tukey Test. }\end{array}$} \\
\hline $\begin{array}{l}\text { Neumann et al. (2018) compared different types } \\
\text { of sealing and also found the influence of plastic } \\
\text { film in sealing of trench silos on the ADG of } \\
\text { feedlot steers, presenting results similar to those } \\
\text { obtained herein. These authors verified ADG of } \\
1.810 \mathrm{~kg} \mathrm{day}^{-1} \text { for animals that received silage }\end{array}$ & \multicolumn{3}{|c|}{$\begin{array}{l}\text { covered with double seal and } 1.565 \mathrm{~kg} \text { day }^{-1} \text { for } \\
\text { animals fed silage sealed with conventional film. } \\
\text { Permeability to } \mathrm{O}_{2} \text { of plastic film is a crucial } \\
\text { factor in maintaining the anaerobic environment } \\
\text { inside the silo, especially in portions of the silo } \\
\text { with greater exposure to the external }\end{array}$} \\
\hline
\end{tabular}


environment, like the sides and the ramp, directly impacting the final quality of the ensiled material and in the productive performance of animals (Bernardes et al., 2012; Neumann et al., 2018).

The DMI (kg day ${ }^{-1}$ ) and DMI (BW\%) of feedlot steers fed corn silage from the feed out face of trench silos were not affected by the different types of sealing $(\mathrm{P}>0.05)$. This differs from that reported by Neumann et al. (2018), who compared double seal and conventional seal, and found that the double seal resulted in greater DMI $\left(\mathrm{kg} \mathrm{day}^{-1}\right)\left(10.04 \mathrm{~kg} \mathrm{day}^{-1}\right.$ against $9.28 \mathrm{~kg}$ day $^{-1}$ ) and DMI (BW\%) (2.30\% against $2.21 \%$ ), due to the better acceptance of silage by animals, as there was no selection or predilection for the concentrate fraction of the diet.

The greater availability of digestible fractions of NDF favors the efficiency of use of the forage offered, contributing to raise the ADG, which is only achieved when there is maintenance of the anaerobic environment inside the silo during fermentation (Neumann et al., 2018). Like ADG, FC was influenced by the type of sealing (P> 0.05). The animals fed silage from the doublesided treatment showed better feed conversion (4.40) than those that received silage preserved from the conventional sealing (5.02), a result justified by the superior ADG (Table 2) of the double-sided sealing, allowing to clearly demonstrate the influence of the type of sealing on the productive performance of confined steers. To achieve a greater ADG, the animals did not need to consume a greater amount of dry matter daily, showing the best use of the roughage fraction of the diet, since the concentrate fraction of the diet was constant throughout the evaluation period for all treatments.
Regarding the feedlot periods (Table 2), regardless of the type of sealing, there was an increase in the ADG ( $\mathrm{P}<0.05)$, from the first to the second period $\left(1.541 \mathrm{~kg}^{-1} \mathrm{day}^{-1}\right.$ against 1.983 $\mathrm{kg}$ day $^{-1}$ ), which can be justified by the increase in the DMI $\left(\mathrm{kg} \mathrm{day}^{-1}\right)(\mathrm{P}<0.05)$, from $7.46 \mathrm{~kg}$ day $^{-1}$ to $8.30 \mathrm{~kg} \mathrm{day}^{-1}$, showing that as the silage unloading advanced into the silo there was a productive increase of the animals, due to better conditions of preservation of the ensiled material in relation to the beginning of the feed out face of the silo. The ingestive behavior of the animals was not affected by the type of sealing and/or the evaluation period $(\mathrm{P}>0.05)$ regarding the feeder and feces scores listed in Table 2, reinforcing that there was no preference for any fraction of the diet supplied to the animals, where scores closer to 3.00 were considered ideal.

The manure production of the animals was lower when fed silage covered with double-faced sealing (12.43 kg NM day ${ }^{-1}$ and $2.40 \mathrm{~kg} \mathrm{DM}$ day $^{-}$ 1 , respectively) in relation to those that received silage from the conventional sealing $(15.84 \mathrm{~kg}$ $\mathrm{NM}$ day $^{-1}$ and $2.85 \mathrm{~kg} \mathrm{DM}$ day $^{-1}$, respectively), however, both did not differ $(\mathrm{P}>0.05)$ from the double seal treatment $\left(13.92 \mathrm{~kg} \mathrm{NM} \mathrm{day}{ }^{-1}\right.$ and $2.62 \mathrm{~kg} \mathrm{DM} \mathrm{day}{ }^{-1}$, respectively) (Table 3). Likewise, the apparent digestibility of DM for the diet of steers fed corn silage from the feed out of trench silos sealed with double-sided film was superior to the other types of sealing, being $4.30 \%$ higher than the apparent digestibility of the diet with silage from the double seal and $11.00 \%$ higher than the conventional seal, a result that shows the better animal performance achieved when using this type of sealing (Table 2 ), demonstrating the best use of the nutrients available in the diet.

Table 3. Average manure production, on natural and dry matter in $\mathrm{kg} \mathrm{day}^{-1}$, and apparent digestibility of feedlot steers fed corn silage from the feed out face of trench silos with different types of sealing

\begin{tabular}{lccc}
\hline \multicolumn{1}{c}{ Types of sealing } & $\begin{array}{c}\text { Manure production } \\
\mathrm{kg} \mathrm{NM} \mathrm{day}^{-1}\end{array}$ & $\begin{array}{c}\text { Manure production } \\
\mathrm{kg} \mathrm{DM} \mathrm{day}\end{array}$ & $\begin{array}{c}\text { Digestibility of DM } \\
\%\end{array}$ \\
\hline Conventional Seal & $15.84 \mathrm{~A}$ & $2.85 \mathrm{~A}$ & $61.80 \mathrm{C}$ \\
Double Sided & $12.43 \mathrm{~B}$ & $2.40 \mathrm{~B}$ & $69.44 \mathrm{~A}$ \\
Double Seal & $13.92 \mathrm{AB}$ & $2.62 \mathrm{AB}$ & $66.74 \mathrm{~B}$ \\
Mean & 14.06 & 2.62 & 65.99 \\
Probability & 0.0169 & 0.0479 & 0.0001 \\
CV $\%$ & 11.84 & 10.73 & 2.42 \\
\hline
\end{tabular}

Averages, followed by upper case letters in the column, differ from each other by the $5 \%$ Tukey Test. 
According to Barros et al. (2011) the apparent digestibility of the diet is mostly dependent on the chemical characteristics of the food, since the fiber portion in general presents less digestibility due to a higher concentration of structural carbohydrates compared to concentrate foods, in addition to generating physical fill of the rumen, reducing the voluntary intake. However, the maintenance of the anaerobic environment inside the silo can promote greater preservation of digestible fractions of the fiber and provide better use by animals (Costa et al., 2005).

Neumann et al. (2018) state that the higher availability of digestible portions of the fiber fraction of the food allows greater digestibility and consequent improvement in the productive performance of confined animals, which is closely related to the ability of the plastic film to keep the environment strictly anaerobic and isolated from changes outside the silo. Thus, it is suggested that this justifies the result obtained in the present study, since the concentrate fraction of the experimental diets remained constant throughout the evaluation period for all types of sealing. Animals that received silage from the conventional seal spentmore hours day ${ }^{-1}$ ingesting food and water (3.19 and 0.33 hours day $^{-1}$, respectively) than those that were fed silage from double-sided seal (2.73 and 0.20 hours day $^{-1}$, respectively) (Table 4), which suggests that these animals fed conventional seal silage had less acceptability to forage and/or spent more time trying to select the diet.

Table 4. Ingestive behavior of activities related to food intake, water intake, rumination and idle, expressed in hours day ${ }^{-1}$, and activities related to feeding, watering, defecation and urination, expressed in number of times day ${ }^{-1}$, of feedlot steers fed corn silage from the feed out face of trench silos with different types of sealing

\begin{tabular}{|c|c|c|c|c|c|c|}
\hline Ingestive & \multicolumn{3}{|c|}{ Types of sealing - Corn Silage } & Mean & $\mathrm{CV}, \%$ & Prob. \\
\hline Behavior & $\begin{array}{c}\text { Conventional } \\
\text { Seal }\end{array}$ & $\begin{array}{c}\text { Double } \\
\text { Sided } \\
\text { Hour }\end{array}$ & $\begin{array}{c}\text { Double } \\
\text { Seal }\end{array}$ & & & \\
\hline Food intake & $3.19 \mathrm{~A}$ & $2.76 \mathrm{~B}$ & $2.78 \mathrm{AB}$ & 2.90 & 17.6 & 0.0499 \\
\hline Water intake & $0.33 \mathrm{~A}$ & $0.20 \mathrm{~B}$ & $0.18 \mathrm{~B}$ & 0.24 & 20.1 & 0.1049 \\
\hline Rumination & $5.53 \mathrm{~A}$ & $5.43 \mathrm{~A}$ & $5.46 \mathrm{~A}$ & 5.47 & 13.60 & 0.9732 \\
\hline Idle & $15.00 \mathrm{~A}$ & $15.68 \mathrm{~A}$ & $15.58 \mathrm{~A}$ & 15.42 & 6.1 & 0.4247 \\
\hline \multicolumn{7}{|c|}{ Number of times day ${ }^{-1}$} \\
\hline Feeding & $17.92 \mathrm{~A}$ & $13.70 \mathrm{~B}$ & $15.17 \mathrm{~B}$ & 15.59 & 22.2 & 0.0315 \\
\hline Watering & $6.50 \mathrm{~A}$ & $4.40 \mathrm{~B}$ & $4.75 \mathrm{~B}$ & 5.21 & 28.7 & 0.0488 \\
\hline Defecation & $7.00 \mathrm{~A}$ & $6.90 \mathrm{~A}$ & $6.00 \mathrm{~A}$ & 6.63 & 25.3 & 0.7360 \\
\hline Urination & $4.67 \mathrm{~A}$ & $5.30 \mathrm{~A}$ & $4.83 \mathrm{~A}$ & 4.93 & 28.6 & 0.8228 \\
\hline
\end{tabular}

Averages, followed by capital letters, on the line, differ by the Tukey Test at $5 \%$.

As for the rumination and idle, expressed in hours day $^{-1}$, these did not suffer interference from the type of sealing $(\mathrm{P}>0.05)$. The time spent on rumination activity is proportional to the cell wall content contained in the forage (Van Soest, 1994), a factor that had no influence on rumination time, since the experimental diets consisted of the same source of forage from the same cultivation area, the same forage: concentrate ratio and the same degree of processing of the particles as listed in Table 1. The animals fed the conventional seal silage spend more time in food and water ingestion, and also accessed the feeder and the feeder more frequently (17.92 times day ${ }^{-1}$ and 6.50 times day ${ }^{1}$, respectively) compared to those fed doublesided silage (13.70 times day ${ }^{-1}$ and 4.40 times day $^{-1}$, respectively) and those fed double seal silage (15.17 times day ${ }^{-1}$ and 4.75 times day ${ }^{-1}$, respectively), which did not differ from each other (P> 0.05) (Table 4). Regarding the frequency of defecation and urination, there was no influence from the type of sealing $(\mathrm{P}>0.05)$, with an average of 6.63 times day $^{-1}$ and 4.93 times day $^{-1}$, respectively.

The time spent in feeding is related to the chemical characteristics of the diets, and foods with a higher concentration of soluble carbohydrates require less time for ingestion and chewing, but the presence of oxygen inside the silo during fermentation leads to consumption of non-structural carbohydrates (Missio et al., 2010; Oba and Allen, 2000). This fact may be related 
to the lower capacity of the conventional seal to block the gas exchange between the internal and the external environment of the silo, reflecting in longer time and higher frequency in food and water intake of animals fed silage from this type of sealing.

It is noteworthy that the types of sealing influenced the ruminal disappearance rate of $\mathrm{DM}$, so that the conventional seal silage presented the lowest rates of ruminal disappearance of DM $\left(0.866 \%\right.$ hour $\left.^{-1}\right)$, compared to the silage obtained from the double-sided and double sealing treatments (1.045\% hour ${ }^{-1}$ and $1.052 \%$ hour $^{-1}$, respectively), with an average $17 \%$ higher than the ruminal degradation of DM in double-sided and double seal compared to conventional seal (Figure 1). After 48hours of incubation, silage covered with double-sided seal showed the highest ruminal disappearance rate $(67.30 \%)$, while the silages of the double seal and the conventional seal had lower $(\mathrm{P}<0.05)$ rates of ruminal disappearance $(64.48 \%$ and $61.87 \%$, respectively).

The preservation of the strictly anaerobic environment makes the fermentation process more efficient, resulting in the preservation of the characteristics of the original ensiled material, favoring better rumen degradability coefficients of DM, allowing to suggest that the silage of the double seal treatment provided the best preservation of the anaerobic environment, restricting the entry of $\mathrm{O}_{2}$ into the silo during fermentation and feeding of the animals (Rooke and Hatfield, 2003). Figure 2 showed that the ruminal disappearance rate of NDF was similar between types of sealing, with values of 0.7709 $\%$ hour $^{-1}$ for double seal silage, $0.7668 \%$ hour $^{-1}$ for double-sided seal silage and $0.75591 \%$ hour $^{-1}$ for conventional seal silage. However, when analyzing the total incubation time of 48hours, the double-sided silage showed the greatest ruminal disappearance of NDF $(44.60 \%)$ while silage of conventional seal showed a lower ruminal disappearance of NDF (42.73\%).

According to Lopes et al. (2015), the digestion of the fiber portion of the food occurs mainly in the rumen and is the result of a dynamic process influenced by the chemical nature of the plant fiber and the rate of passage through the gastrointestinal tract of the animal. The rapid disappearance of NDF in the rumen is related to high fiber degradation and higher rate of passage, enabling greater voluntary intake of the food due to low physical fill of the rumen (Oba e Allen, 2000).

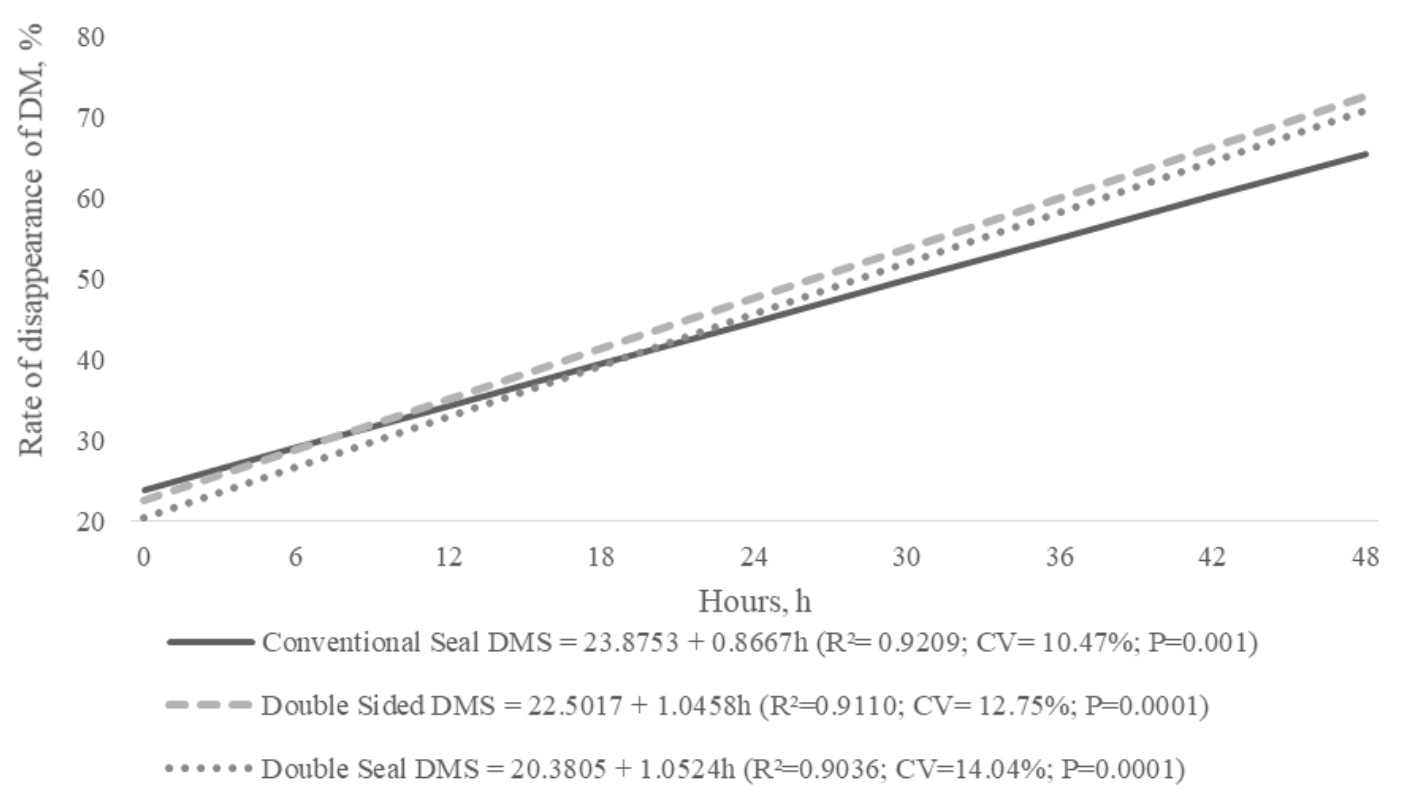

Figure 1. In situ ruminal dry matter disappearance rate of corn silage from the feed out face of trench silos with different types of sealing. 


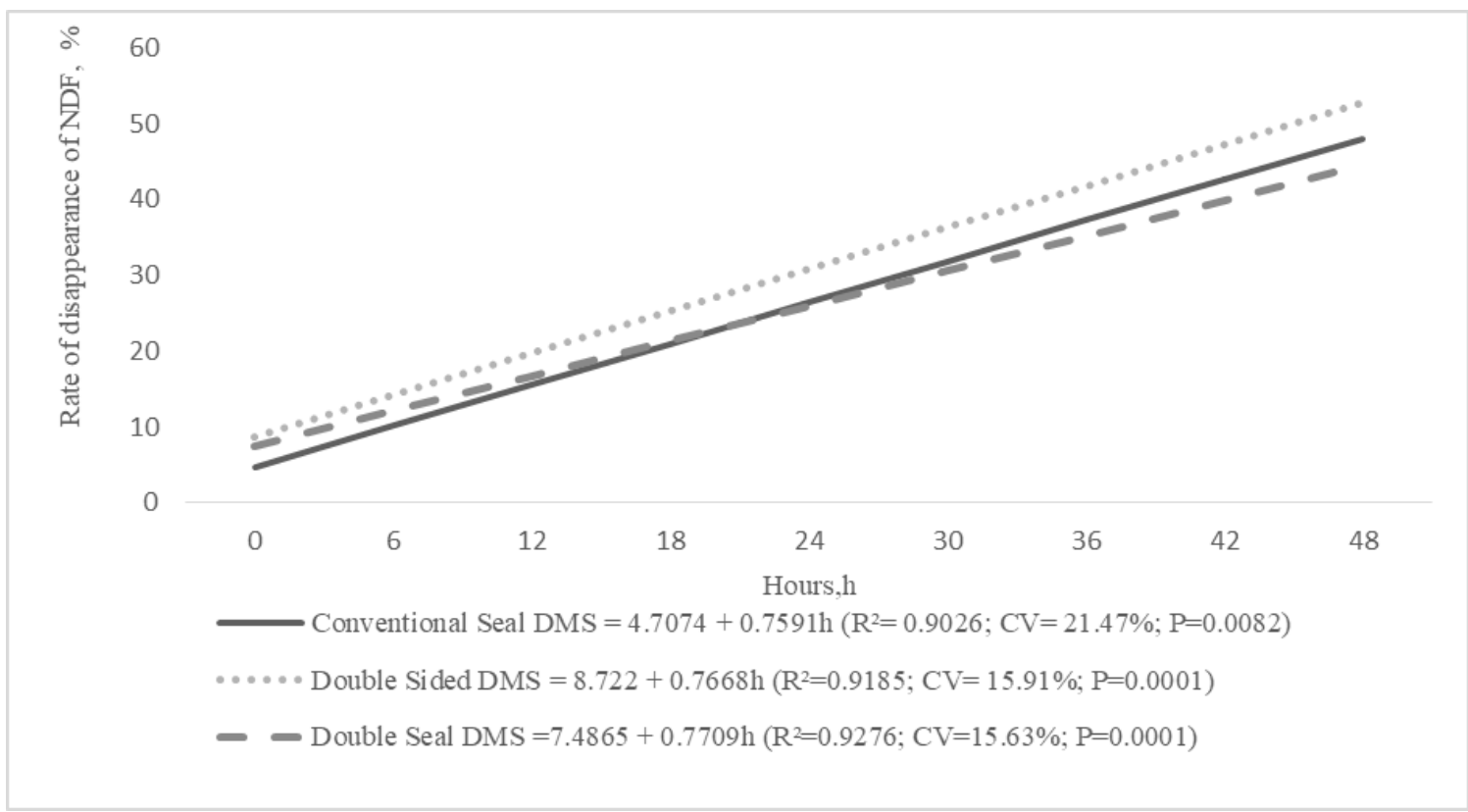

Figure 2. In situ ruminal disappearance rate of neutral detergent fiber of corn silage from the feed out face of trench silos with different types of sealing.

The presence of oxygen inside the silo combined with the availability of substrate stimulates the growth of yeasts that degrade non-fiber carbohydrates, causing an increase in the concentration of fiber carbohydrates and/or indigestible components due to the concentration effect, these carbohydrates being less digestible (Rooke \& Hatfield, 2003). The better use of the fiber portion of the silage has a positive correlation with responses in increasing milk and meat production (Barlow et al., 2012). The digestibility of corn silages is extremely important, as foods with better digestibility values allow greater intake of dry matter, better use of the food supplied, allowing productive increases and collaborating to dilute production costs (Ferraretto and Shaver, 2015; Neumann et al., 2017).

\section{CONCLUSIONS}

The double-sided seal with a thickness of $200 \mu \mathrm{m}$ and the double seal made of double-sided polyethylene overlying a polyamide film showed similar results and their use is recommended for sealing the feed out face of trench silos. It is not recommended to use double-sided polyethylene seal with less than $200 \mu \mathrm{m}$ thick to preserve corn silage from the feed out face of trench silos.

\section{REFERENCES}

BARLOW, J.S.; BERNARD, J.K.; MULLIS, N.A. Production response to corn silage produced from normal, brownmidrib, or waxy cornhybrids. J. Dairy Sci., v.95, p.4550-4555, 2012.

BARROS, R.C.; ROCHA JÚNIOR, V.R.; SARAIVA, E.P. et al. Comportamento ingestivo de bovinos nelore confinados com diferentes níveis de substituição de silagem de sorgo por cana-de-açúcar ou bagaço de cana amonizado com ureia. Rev. Bras. Ciênc. Vet., v.18, p.6-13, 2011.

BERNARDES, T.F. Advances in silage sealing. In: SILVA, T.; SANTOS, E.M. (Eds.). Advances in silage production and utilization. Croatia: Rijeka, 2016. p.53-62.

BERNARDES, T.F.; NUSSIO, L.G.; AMARAL, R.C. Top spoilage losses inmaize silage sealed with plastic films with different permeabilities to oxygen. Grass Forage Sci., v.67, p.34-42, 2012.

BERNARDES, T.F.; SCHMIDT, P.; DANIEL, J.L.P. An overview of silage production and utilization in Brazil. In: INTERNATIONAL SILAGE CONFERENCE, 17., 2015, Piracicaba. Proceedings... Piracicaba: ESALQ, 2015. p.124144. 
BORREANI, G.; TABACCO, E.; CAVALLARIN, L. A new oxygen barrier film reduces aerobic deterioration in farm-scale corn silage. J. Dairy Sci., v.90, p.4701-4706, 2007.

COSTA, M.A.L.; VALADARES FILHO, S.D.C.; PAULINO,M.F. et al. Desempenho, digestibilidade e características de carcaça de novilhos zebuínos alimentados com dietas contendo diferentes níveis de concentrado. Rev. Bras. Zootec., v.34, p.268-279, 2005.

FERRARETTO, L.F.; SHAVER R.D. Effect sofwhole-plant corn silagehybrid type on intake, digestion, ruminal fermentation, and lactation performance by dairy cows through ametaanalysis. J. Dairy Sci., v.98, p.2662-2675, 2015.

FERREIRA, S.F.; GUIMARÃES, T.P.; MOREIRA, K.K.G. et al. Caracterização fecal de bovinos. Rev. Ciênt. Eletr. Med. Vet., v.20, p.1-22, 2013.

GOERING, H.K.; VAN SOEST, P.J. Forage fiberanalysis: apparatusreagents, procedures and some applications. Washington, D. C: [sn], 1970. (AgriculturalHandbook p.379).

KUNG JUNIOR, L. What's new in silagemanagement. Madison: University of Delaware, 2005. p.159-165.

LOOPER, M.L.; STOKES, S.R.; WALDNER, D.N.; JORDAN, E.R. Managingmilk composition: evalua tingherd potencial. New Mexico: Cooperative Extension Service College of Agricultureandhome Economics, New Mexico State University. Cooperative Extension Service, 2001.

LOPES, F.; COOK, D.E.; COMBS, D.K. Validation of an in vitromodel for predicting rumen and total-tract fiber digestibility in dairy cows fed corn silage swith different in vitro neutral detergent fiber digestibiliti esat 2 levels of drymatter intake. J. Dairy Sci., v.98, p.574585,2015

MISSIO, R.L.; BRONDANI, I.L.; ALVES FILHO, D.C. et al. Comportamento ingestivo de tourinhos terminados em confinamento, alimentados com diferentes níveis de concentrado na dieta. Rev. Bras. Zootec., v.39, p.1571-1578, 2010.
NEUMANN, M.; LEÃO, G.F.M.; ASKEL, E.J. et al. Sealing type effect on corn silage quality in bunker silos. Ciênc. Rural, v.47, p.1-6, 2017.

NEUMANN, M.; LEÃO, G.F.M.; SANTOS, L.C. et al. Uso de dupla vedação em silagem de milho sobre o desempenho de novilhos confinados. Rev. Ciênc. Agrovet., v.17, p.100106, 2018.

NOCEK, J.E. In situ and othermethods to estimate ruminal protein and energy digestibility: a review. J. Dairy Sci., v.71, p.2051-2069, 1988.

OBA, M.; ALLEN, M.S. Effects of brownmibrib 3 mutation in corn silage on productivity of dairy cows fed two concentrations of dietary neutral detergent fiber: 1. Feeding behavior an nutrient utilization. J. Dairy Sci., v.83, p.1333-1341, 2000.

OFFICIAL methods of analysis. 16.ed. Washington: AOAC, 1995.

ROOKE, J.A.; HATFIELD, R.D. Biochemistry of ensiling. Silage Sci. Technol., v.42, p.95-139, 2003.

SAS/STAT user's guide: statistics. Version 6. 4.ed. North Caroline: SAS Institute, 1993. v.2, 943p.

VAN SOEST, P.J. Nutritional ecology of the ruminant. 2 ed. Ithaca, NY: Cornell University Press, 1994. 476p.

VAN SOEST, P.J.; ROBERTSON, B.A.; LEWIS, B.A. Methods for dietary fiber, neutral detergent fiber, and nonstarch polysaccharides in relation to animal nutrition. J. Dairy Sci., v.74, p.3583-3597, 1991.

WEISS, W.P.; CONRAD, H.R.; PIERRE, N.S. A the o retically basedmodel for predicting total digestible nutrient values of forages and concentrates. Anim. Feed Sci. Technol., v.39, p.95-110, 1992.

WILKINSON, J.M.; DAVIES, D.R. The aerobic stability of silage: key findings and recent developments. Grass Forage Sci., v.68, p.1-19, 2013. 